\title{
ANÁLISE DA PERCEPÇÃO AMBIENTAL DOS MORADORES DO ENTORNO DAS LAGOAS DE PIRATININGA E ITAIPU, NITERÓI (RJ)
}

\author{
Elaine Ferreira da Silva ${ }^{1}$ \\ Dirlane de Fátima do Carmo² \\ Mariana Vezzone ${ }^{3}$ \\ Roberto Meigikos dos Anjos ${ }^{4}$ \\ Lara Novis Lemos Machado ${ }^{5}$ \\ Ana Beatriz de Lima Santana Correio ${ }^{6}$ \\ Igor Picinin Rocha Affonso Nogueira ${ }^{7}$ \\ Letícia Nascimento Pecly ${ }^{8}$
}

Resumo: Neste estudo foi analisada a percepção ambiental de moradores da Região Oceânica de Niterói (RJ), e avaliada a sua relevância como instrumento de apoio à gestão ambiental municipal. Para isso, foram entrevistados 90 moradores da região do entorno das lagoas de Piratininga e Itaipu. Os resultados revelaram que grande parte dos entrevistados demonstrou conhecer conceitos ambientais e ações desejáveis para evitar ou mitigar impactos negativos. Porém, apesar de se reconhecerem como parte da solução, a maioria não se envolve em ações públicas que contribuam para melhoria do meio ambiente. Demonstra-se, assim, a importância da percepção ambiental como ferramenta de gestão, que visa promover ações de educação ambiental.

Palavras-chave: Gestão Ambiental; Região Oceânica de Niterói; Abordagem Crítica; Educação Ambiental.

${ }^{1}$ Universidade Federal Fluminense. E-mail: elainefs@id.uff.br. Lattes: http://lattes.cnpq.br/3922841596916092

2 Universidade Federal Fluminense. E-mail: dirlanefc@id.uff.br. Lattes: http://lattes.cnpq.br/4363007491068841

3 Universidade Federal Fluminense. E-mail: mvezzone@id.uff.br. Lattes: http://lattes.cnpq.br/3480934637599701

4 Universidade Federal Fluminense. E-mail: meigikos@mail.if.uff.br. Lattes: http://lattes.cnpq.br/8992343089719806

5 Instituto Federal do Rio de Janeiro. E-mail: laranovis@gmail.com. Lattes: http://lattes.cnpq.br/4968156725157864

6 Universidade Federal Fluminense. E-mail: ana_blimasantana@hotmail.com. Lattes: http://lattes.cnpq.br/7774475192984457

7 Universidade Federal Fluminense. E-mail: igorpicinin@id.uff.br. Lattes: http://lattes.cnpq.br/1144381726665750

8 Universidade Federal Fluminense. E-mail: lelenascpecly@gmail.com. 
Abstract: This study aims to analyze the environmental perception of residents (Piratininga and Itaipu) and discuss its relevance as an instrument to support municipal environmental management. For this, 90 residents of the region surrounding the Piratininga and Itaipu lagoons (RJ, Brazil) were interviewed. The results showed that a large part of the interviewees demonstrated to know environmental concepts and desirable actions to avoid or mitigate impacts. However, despite recognizing themselves as part of the solution, most do not engage in public actions to improve the environment, showing discredit in relation to this. This demonstrates the importance of environmental perception as a management tool, aiming to promote environmental education actions.

Keywords: Environmental Management; Oceanic Region of Niterói; Critical Approach; Environmental Education.

\section{Introdução}

A partir da década de 90 , os estudos sobre percepção ambiental adquiriram significado e relevância nas políticas públicas e na implantação de suas ações, principalmente em se tratando dos problemas relacionados ao meio ambiente, transformações e mudanças de atitudes e condutas das comunidades (GUIMARÃES, 2003). A percepção ambiental perpassa pelo reconhecimento da inserção do homem em determinado ambiente e as distintas formas de sua interpretação em relação ao seu meio. A partir dessa percepção nascem as políticas públicas, relacionadas ao ambiente de cada sociedade (RODRIGUES; GOUVEIA, 2014).

De acordo com Vicente et al., (2015), uma parte significativa da população ainda não é capaz de identificar as ações relacionadas ao meio ambiente, infraestrutura, questão social e recursos hídricos de forma positiva. Contudo, estudos de percepção ambiental são uma importante ferramenta para a elaboração de ações mitigadoras, na medida em que buscam entender o modo como a comunidade se envolve com o meio ambiente onde vive, sendo essa relação de ordem cognitiva, afetiva e ética (LIMA, 2015; TERAMUSSI, 2008). Dessa forma, perceber o ambiente no qual se está inserido é imprescindível para que o indivíduo possa aprender a respeitá-lo e preservá-lo.

Os bairros de Itaipu e Piratininga, localizados na região das praias oceânicas de Niterói, são de grande importância do ponto de vista ambiental. Suas lagoas (Piratininga e Itaipu, respectivamente) são importantes polos de turismo e lazer do Estado do Rio de Janeiro, compreendendo uma área total de $3,87 \mathrm{~km}^{2}$, além de mais $2 \mathrm{~km}^{2}$ de área alagadiça (PROJCONSULT, 2015). Por estarem inseridas no Bioma Mata Atlântica, são consideradas bons exemplos de hotspots: regiões de elevada biodiversidade, mas que se encontram sob ameaça extrema (BRANDON et al., 2005).

Embora a área do entorno da lagoa de Itaipu tenha sido anexada ao Parque Estadual da Serra da Tiririca (PESET), uma Unidade de Conservação de proteção integral, através do Decreto Estadual no 41.266 de 2008. Ela

apresenta uma ocupação residencial significativa, com a presença de diversos 
condomínios de casas e apartamentos, além de outras moradias de luxo, classe média e de baixa renda. Em suas vias principais, destacam-se também várias edificações comerciais (RIO DE JANEIRO, 2008).

Nesta região, existe também a Reserva Extrativista Marinha de Itaipu (RESEX Itaipu), criada em 2013, como a primeira Unidade de Conservação Estadual dessa categoria (INEA, 2020). Neste mesmo ano, iniciou-se uma gestão compartilhada entre o Município de Niterói e o Governo do Estado do Rio de Janeiro referente a região hidrográfica das lagunas. Contudo, de acordo com o Plano de Manejo do PESET, dentre os impactos ambientais negativos registrados no entorno das Lagoas de Piratininga e Itaipu, destacam-se a ocupação irregular e a ligação clandestina de esgoto doméstico (SEA, 2015).

Segundo o estudo realizado pela empresa HydroScience (2018), referente a "Evolução Histórica dos Usos do Sistema Lagunar e seu Entorno", a Região Hidrográfica destas Lagunas é constituída de ecossistemas aquáticos, conectados permanentemente entre si desde 1940 (Canal de Camboatá) e, com o mar, desde 1979 (canal do Tibau em Piratininga e canal da lagoa de Itaipu). As obras para a construção do canal artificial do Camboatá provocaram o esvaziamento da lagoa de Piratininga, reduzindo sua lâmina d'água, que culminaram no surgimento de áreas marginais secas. Isto acarretou alterações drásticas na paisagem da região, que sofreu danos ainda mais severos com a ocupação irregular ao longo dos últimos 42 anos. O estudo da HydroScience (2018) também relatou outros cenários vulneráveis das lagunas relativos a baixa qualidade das águas, como a presença de processos de eutrofização, oriundos da falta de infraestrutura e saneamento básico, que geram aportes elevados de sedimentos e carga orgânica para as lagoas de Itaipu e Piratininga. A pesca artesanal predatória também tem contribuído para a degradação ambiental (HYDROSCIENCE, 2018).

Em 2008, foi realizada a construção do Túnel do Tibau, a fim de conectar a lagoa de Piratininga com o mar. Embora este acesso nunca tenha funcionado adequadamente, com seguidos episódios de obstrução e desobstrução do túnel, a situação agravou-se no início de 2019, quando houve um desmoronamento de rochas no Túnel do Tibau, comprometendo em definitivo o fluxo hídrico dos sistemas lagunares (NITERÓl, 2020). Atualmente, ações de alinhamento estão sendo tomadas para a intervenção e obras necessárias para estabelecer o fluxo hídrico entre a Lagoa de Piratininga e o mar e subsidiar o planejamento das ações de recuperação ambiental dos sistemas. Niterói lançou o PRO-Sustentável (Programa Região Oceânica Sustentável), que tem como destaque três componentes principais para esta área de estudo: infraestrutura, urbanização e sustentabilidade ambiental. De acordo com informações divulgadas pela Prefeitura Municipal de Niterói, uma das principais prioridades deste programa é a de estabelecer um Plano de Gestão Ambiental para toda a Região Oceânica (PROSUSTENTAVEL, 2020).

Apesar da mobilização da prefeitura de Niterói por ações de recuperação das Lagoas de Piratininga e Itaipu, até o momento, não foram evidenciados estudos de percepção ambiental para este local. Analisar a 
percepção ambiental de seus moradores possibilitaria verificar como eles intervêm nesse espaço, como são afetados, bem como proporcionaria uma análise crítica da postura da população em relação às ações do poder público local. Permitiria, portanto, verificar se a estratégia de ação adotada é adequada.

Assim, este trabalho teve como objetivo central, analisar a percepção ambiental de moradores da região das praias oceânicas de Niterói, especificamente situadas no entorno das lagoas de Piratininga e Itaipu, sobre a conservação ambiental local e discutir sua relevância como ferramenta de apoio para a gestão ambiental municipal.

\section{Área de Estudo}

O município de Niterói pertence à Região Metropolitana do Estado do Rio de Janeiro. Limita-se ao norte-noroeste com o município de São Gonçalo; ao leste, com Maricá; ao sul, com o Oceano Atlântico e; ao oeste, com a Baía de Guanabara (Figura 1). Com cerca de 500.000 habitantes e uma área de $133.916 \mathrm{~km}^{2}$, Niterói possui 52 bairros, que estão agrupados em cinco regiões administrativas (IBGE, 2015).

A Região Oceânica de Niterói compreende uma área com cerca de $50 \mathrm{~km}^{2}$, com costas orientadas no sentido Leste-Oeste. É dotada de unidades geomorfológicas extremamente dinâmicas, e posicionadas em um contexto de alta valorização imobiliária. Suas praias, lagoas, rios e serras são cobertas de vegetação nativa da Mata Atlântica, formando um raro conjunto paisagístico, cuja beleza e importância ultrapassam os limites municipais.

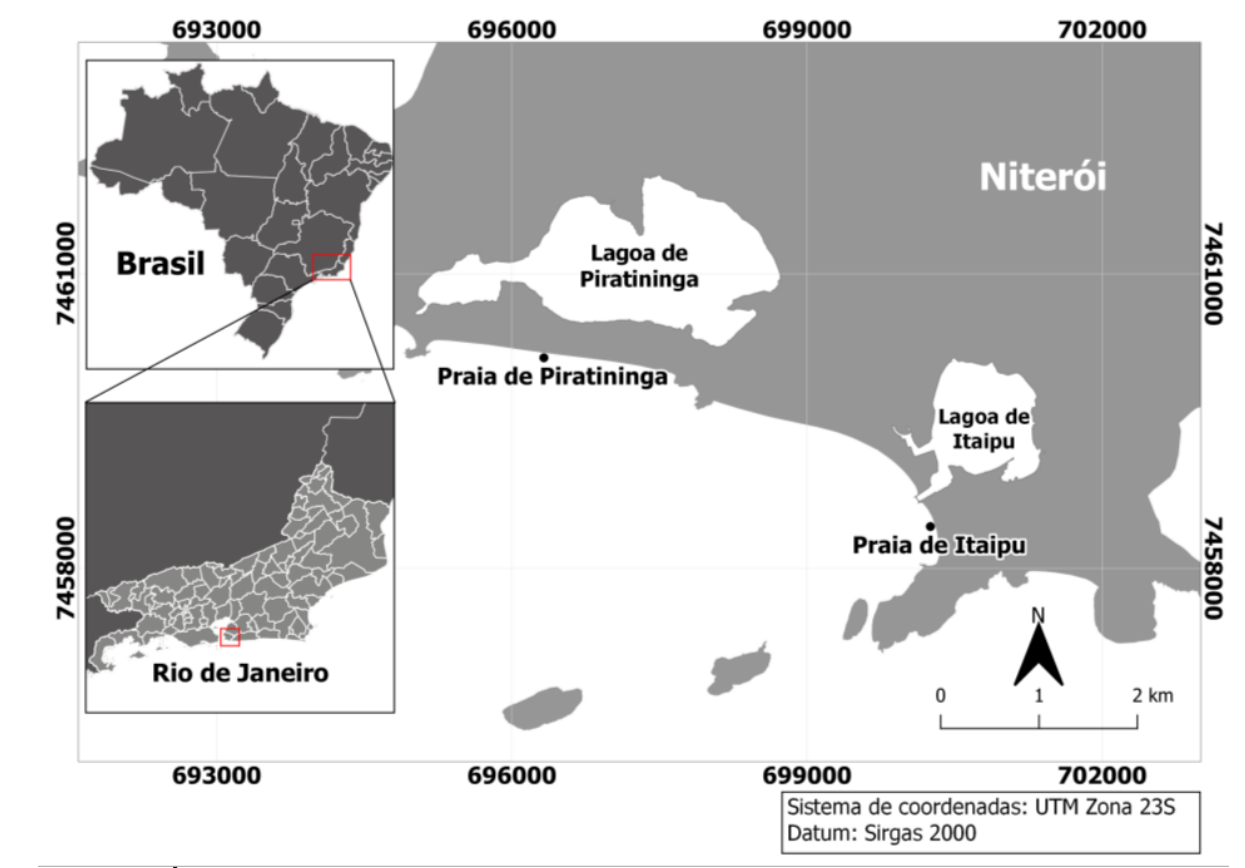

Figura 1: Área de estudo com Piratininga e Itaipu em destaque (praias e lagoas).

Fonte: SIGeo Niterói 
O bairro de Itaipu é considerado o mais desenvolvido da Região Oceânica de Niterói, devido à presença de uma extensa rede de comércios e serviços, que atendem aos demais bairros ao seu redor. Abriga escolas, serviços públicos de saúde, restaurantes, shoppings e lojas comerciais. O setor residencial que se desenvolveu principalmente, no entorno da Lagoa de Itaipu e baixada litorânea, é constituído de uma população de estratificação social diversificada, refletindo, deste modo, a realidade brasileira. Contudo, a classe média é a que apresenta a maior parcela entre os seus 6.320 habitantes (IBGE, 2015).

A enseada de Itaipu apresenta uma das praias mais famosas da Região Oceânica (Figura 1). As atividades turísticas, principalmente nos períodos de alta estação, são importantes para a economia da comunidade local. Seu formato de enseada também atua como abrigo para diversas embarcações, (CARVALHIDO, 2012). Em meados da década de 1920, foi fundada uma comunidade de pescadores artesanais tradicionais: a Colônia de Pesca (Z-7). Mais tarde, surgiram outras associações de pescadores, como a Associação Livre dos Pescadores e Amigos da Praia de Itaipu, que fazem com que a pesca artesanal também tenha grande destaque nas atividades socioeconômicas e culturais da região. A Lei Municipal no 2.874/2011 reconheceu a pesca artesanal de Itaipu como Patrimônio Cultural Imaterial da cidade de Niterói (NITERÓI, 2011). Entretanto, devido à expansão urbana e imobiliária da região, somadas a pesca industrial e a poluição das águas marinhas, essa comunidade está sendo ameaçada e já apresentou uma redução significativa no número de pescadores (SEA, 2013).

$O$ bairro de Piratininga localiza-se no entorno da laguna de mesmo nome, limítrofe aos bairros de Camboinhas, Itaipu, Cafubá, Charitas e Jurujuba (Figura 1). Possui uma população residente de 16.098 habitantes (IBGE, 2015), predominantemente de classe média. A exceção está nas áreas ao redor da laguna, que são ocupadas, em sua maioria, por pescadores, constituindo uma população de baixa renda. O bairro possui uma concentração significativa de pequenos estabelecimentos comerciais e restaurantes, que junto com a beleza natural de sua praia atraem muitos turistas no verão, representando outro importante núcleo de lazer do município. Assim, as lagoas de Piratininga e Itaipu apresentam-se como importantes polos de turismo e lazer do Estado do Rio de Janeiro.

\section{Metodologia}

Este trabalho foi pautado em dados obtidos por meio da aplicação de um questionário fechado e estruturado, a uma amostra da população que se desejou conhecer e, com posterior análise qualitativa dos resultados (RAUPP e BEUREN, 2006; SILVA et al., 2011), se caracterizando como uma pesquisa descritiva e exploratória. No âmbito de classificação, a pesquisa realizada foi de natureza aplicada, uma vez que visou gerar conhecimentos com finalidade de aplicação prática, voltada a solucionar problemas específicos, além de abranger verdades e interesses locais (SILVA; MENEZES, 2005).

Revbea, São Paulo, V. 16, № 2: 446-469, 2021. 
A escolha de questionários para análise da percepção ambiental foi pautada em Faggionato (2002), que aponta o uso de questionários, mapas mentais e até representação fotográfica, como as diferentes formas de se abordar a percepção ambiental. A fim de promover a sensibilização e compreensão do entrevistado, com foco no envolvimento do indivíduo com o meio ambiente.

O número de entrevistas foi determinado seguindo critérios estatísticos de amostragem probabilística (ADDISON, 2003; FONSECA; MARTINS, 1996). As coletas de dados foram realizadas no período compreendido entre janeiro e março de 2020, resultando numa amostra de 90 entrevistas. A população amostral contemplou adultos com idade acima de 18 anos, sendo a participação de forma voluntária e a abordagem ocorreu nos domicílios. Para a obtenção de informações sobre o posicionamento de cada individuo em relação a temas ambientais, foram realizadas 30 perguntas, subdivididas em tópicos sobre Perfil (gênero, idade, nível de escolaridade), Meio Ambiente (percepção ambiental) e Políticas Públicas Ambientais (percepção sobre as ações ambientais dos poderes publicos).

Durante o processo de análise dos dados quantitativos foi utilizado o Software SPSS v15 (Statistical Package for the Social Sciences), um programa especializado em análise de dados. Foi utilizada também a técnica de Mineração de Palavras, onde foi possível criar nuvens de palavras, através do Word Clouds, um gerador on line, que ilustra o discurso dos participantes para facilitar na análise de dados.

\section{Resultados e Discussão}

De acordo com o Censo (2010), a população feminina de Piratininga e Itaipu é $52 \%$ superior a masculina, conforme apresentado na Tabela 1. Esta superioridade também foi mantida na aplicação dos questionários, onde $64 \%$ dos participantes eram do gênero feminino.

Tabela 1: Comparação entre as populações de Piratininda e Itaipu.

\begin{tabular}{r|ll} 
& Piratininga & Itaipu \\
\hline População Homens & 7.849 & 3.016 \\
População Mulheres & 8.249 & 3.304
\end{tabular}

Fonte: Adaptado de IBGE (2010).

Em relação a faixa etária dos participantes, foi dividida por grupos etários, $37 \%$ representaram um grupo de 18 a 30 anos, 29\% representaram um grupo de 31 e 49 anos e com 34\% um grupo igual ou superior a 50 anos de idade. A partir da Figura 2, pode-se avaliar a contagem da tabulação cruzada: Grau de instrução e Gênero.

Revista brasileira educação ambiental 


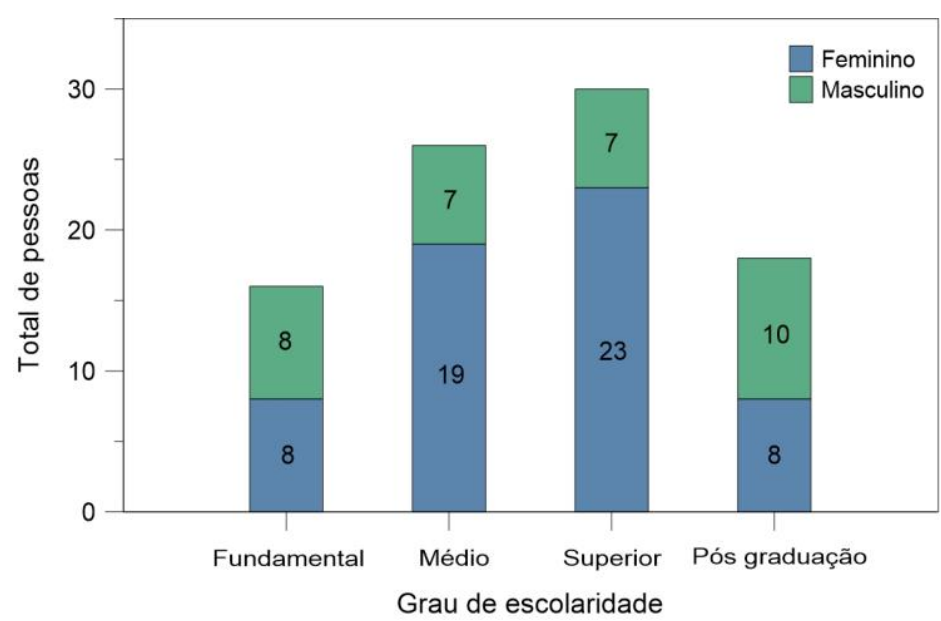

Figura 2: Tabulação cruzada sobre Gênero e Grau de Instrução.

Segundo o perfil de nível de escolaridade, dividido em nível superior com $33 \%$, pós-graduação com $20 \%$, nível médio com $29 \%$ e ensino fundamental com 18\%. Destacando-se ainda que do grupo com idade entre 18 e 30 anos, mais da metade apresentava com nível superior e pós-graduação. É importante mencionar que esta distribuição não reflete a realidade brasileira, pois, segundo o censo do IBGE (2010), 49,25\% da população brasileira com mais de 25 anos não possui sequer o ensino fundamental completo e apenas $11,26 \%$ possuem ensino superior completo. No entanto, ela pode auxiliar na compreensão dos dados coletados para avaliar a percepção ambiental dos moradores.

Tabela 2: Perfil dos entrevistados - Nível de escolaridade e faixa etária. 18 a 30 anos 31 a 49 anos Igual ou superior a 50 anos

\begin{tabular}{r|rrr} 
Fundamental & $6 \%$ & $12 \%$ & $35 \%$ \\
Médio & $27 \%$ & $31 \%$ & $29 \%$ \\
Superior & $55 \%$ & $31 \%$ & $13 \%$ \\
Pós-graduação & $12 \%$ & $27 \%$ & $23 \%$
\end{tabular}

Fonte: Autoria própria (2020).

Referente ao número de moradores por domicílio, verificou-se que a quantidade variou entre um e seis indivíduos por família, destacando-se $64 \%$ de 3 a 5 pessoas. No que se refere ao tempo de moradia na região, $21 \%$ reside na região menos de 5 anos, $28 \%$ reside de 5 a 10 anos, $28 \%$ de 10 a 20 anos e $23 \%$ a mais de 20 anos.

Quando solicitado para cada entrevistado que citasse uma palavra que representasse para ele o significado da lagoa, a mais evidenciada foi, Vida representando $13 \%$, sequenciando com natureza $11 \%$, local onde eu vivo $8 \%$, beleza $6 \%$, paz $4 \%$ e família $3 \%$. Esta abordagem revelou sentimentos muito positivos e até mesmo de muito orgulho de seu principal espaço ou habitat. 
Apesar do aspecto positivo predominar, foi observada uma insatisfação pelo cenário atual das lagoas ainda que um percentual mínimo, registrando palavras como tristeza, poluída e abandono, conforme exposto na Figura 3.

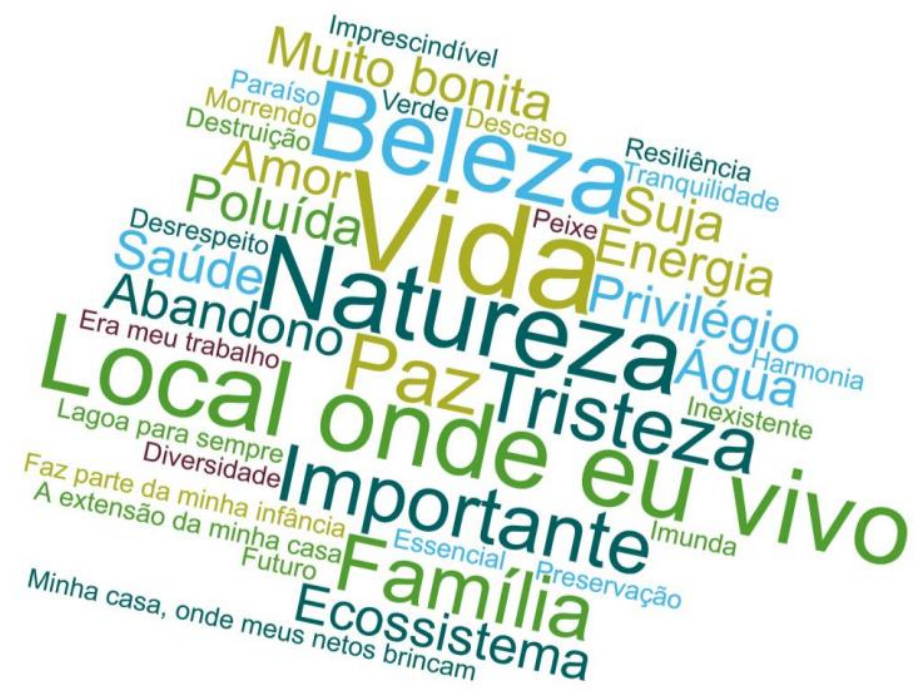

Figura 3: Frequência das respostas obtidas em relação ao significado das lagoas.

Na Região Oceânica de Niterói há nove associações de moradores, sendo cinco em Piratininga e quatro em Itaipu. Quando os entrevistados foram questionados se tinham ciência da existência de associações, $71 \%$ declararam que sim, enquanto $29 \%$ não. Contudo, apenas $22 \%$ dos entrevistados afirmaram participar de ações promovidas por essas associações. Isto demonstrou claramente que há uma falta de engajamento dos moradores em relação à atuação desses movimentos sociais. Através da Figura 4 é possível avaliar o percentual por tabulação cruzada, considerando a ciência sobre a existência das associações em relação a participação efetiva em alguma delas. Em 1999, Ferreira já apontava essa tendência precária da participação política dos moradores de um determinado local. Apesar de haver um crescimento significativo de associações de moradores, a ausência de engajamento reflete a falta de confiança do brasileiro na qualidade de sua representação ou até por não acreditarem na política como mecanismo de representação. Considerando que a população amostrada neste trabalho possui um nível de ensino elevado e mesmo assim, se mantém alheia a existência de movimentos sociais, é um dado preocupante.

Uma associação de moradores representa um papel importante como instrumento da participação comunitária, uma vez que promove discussões e encaminhamentos pertinentes aos assuntos e problemas locais. A associação de moradores surge para a cooperação mútua, em práticas com o intuito de lutar pelo bem comum de um conjunto de pessoas, podendo atuar em diferentes setores da sociedade. Considerando que o associativismo é um princípio para o crescimento de uma sociedade, regido por liberdade, democracia e solidariedade, ao abdicar da participação mútua, a população

Revista brasileira educação ambiental 
também renuncia a um de seus principais instrumentos capaz de produzir uma melhoria local (PRATTES, 2013).

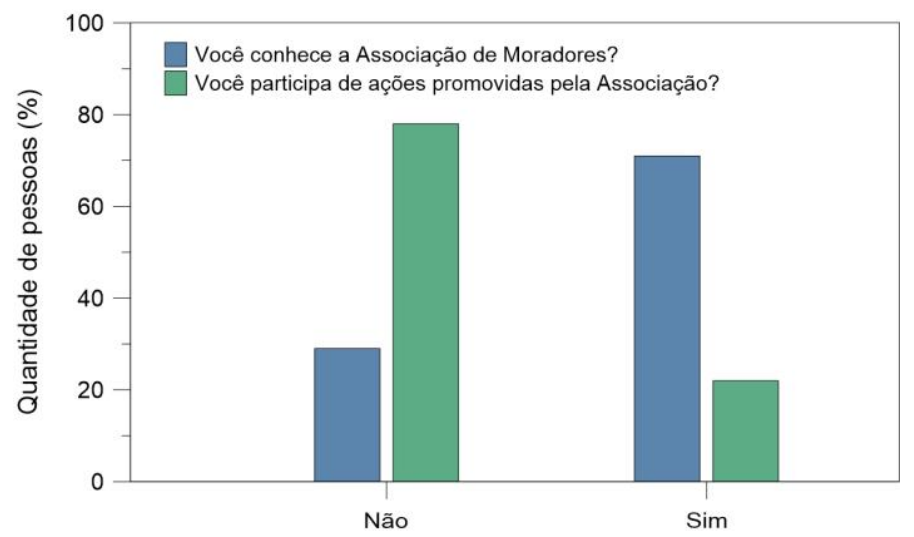

Figura 4: Tabulação cruzada sobre o conhecimento de Associação dos Moradores.

Com a finalidade de identificar qual seria o embasamento de cada entrevistado que sustenta sua percepção ambiental, foi perguntado: "De acordo com sua compreensão, o que você entende por Meio Ambiente?". Os perfis de maiores percentuais para Natureza com $12 \%$ e local onde eu vivo com $8 \%$, conforme exposto a seguir na Figura 5.

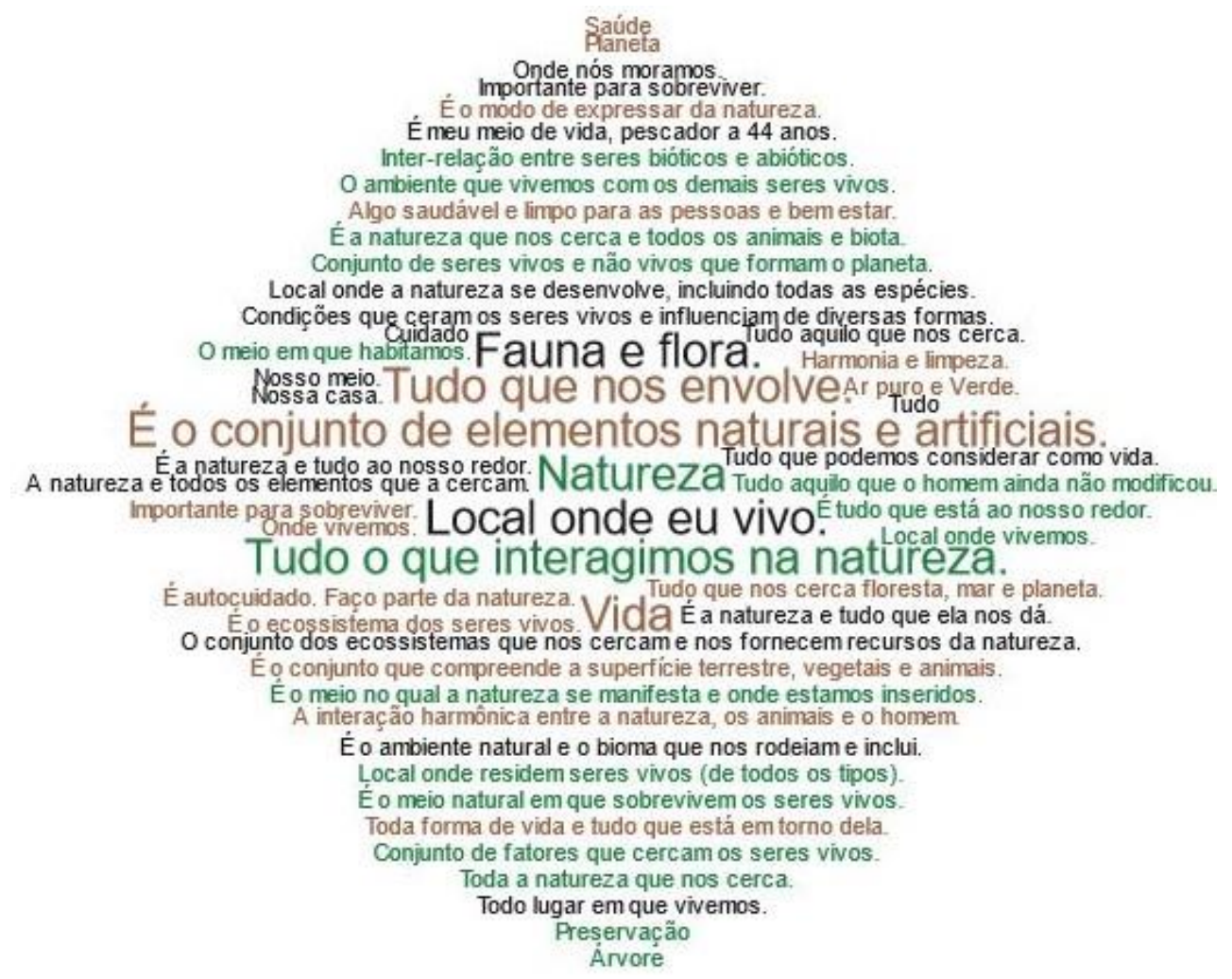

Figura 5: Frequência das respostas obtidas em relação a compreensão de Meio Ambiente.

Revista brasileira

educação ambiental 
É sutil a diferença entre essas percepções. O conceito de "Natureza", de acordo com Krzysczak (2016, p. 6), reporta a uma percepção em que o homem está dissociado do ambiente, que é visto como puro, algo que deve ser admirado, respeitado e com o qual se deve aprender a relacionar. Enquanto a percepção do conceito "local onde eu vivo" está alinhada ao conceito de meio ambiente. Conforme proposto por Coimbra (1985, p. 21), meio ambiente está associado ao conjunto dos elementos físico-químicos, ecossistemas naturais e sociais em que se insere o Homem (seja de maneira individual e socialmente) num processo de interação que atenda ao desenvolvimento das atividades humanas, à preservação dos recursos naturais e das características essenciais do entorno, dentro de padrões de qualidade definidos. A insatisfação pelo cenário atual das lagoas demonstra, como citado por Reigota (2007) que o conceito de ambiente evoluiu no tempo e depende do grupo social que o utiliza, da formação profissional das pessoas, de suas vivências, do lugar onde vivem.

Também foi indagado sobre a origem das informações sobre as questões ambientais que cada entrevistado adquiria no dia a dia. Uma grande parcela dos entrevistados $81 \%$, respondeu que das mídias (Tv, Rádio, Jornal, Revistas, Internet, WhatsApp), e como o principal meio de informação, foi evidenciado a Internet (Figura 6). A Internet teve seu avanço superior a qualquer outro veículo de comunicação já instituído e se popularizou especialmente a partir da década de 1990. Nos dias atuais a quantidade de informações a que a população tem acesso é infinita, muitas pessoas buscam a internet com 0 intuito de ampliar horizontes, e muitas pessoas utilizam também para se manterem circuladas de seus interesses fazendo reafirmar as suas visões de mundo, e possivelmente excluindo aqueles que pensam de forma diferente (HUTTNER, 2020).

Verifica-se, assim, que as mídias sociais podem ser utilizadas em inúmeras atividades para proporcionar um aumento de consciência crítica do cidadão, que auxilia na socialização da informação, atingindo diferentes estratos da sociedade. Sendo uma ferramenta de educação ambiental, considerada por Domenes et al., (2012, p. 123), como uma das maneiras mais eficazes de levar a informação para a população.

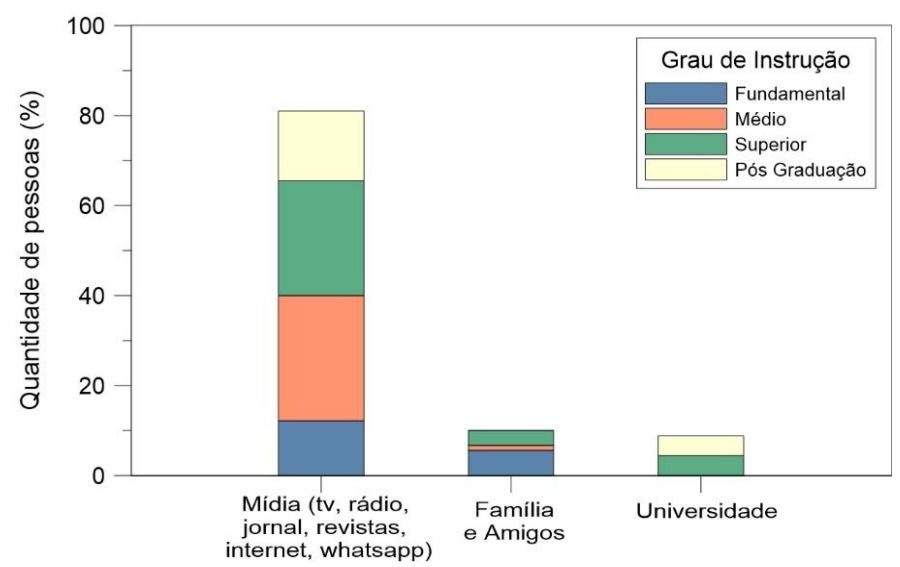

Figura 6: Informações sobre as questões ambientais no dia a dia e grau de instrução. 
Quando indagados se conversavam com os vizinhos sobre meio ambiente, $67 \%$ responderam que sim. Segundo este grupo, os assuntos mais abordados nestes diálogos foram poluição com $34 \%$ e lixo ou resíduos com $33 \%$.

De acordo com a Figura 7 observa-se a representação da contagem por tabulação cruzada do impacto ambiental com o grau de instrução. Quando questionados se sabiam o que era Impacto Ambiental, $89 \%$ responderam que sim.

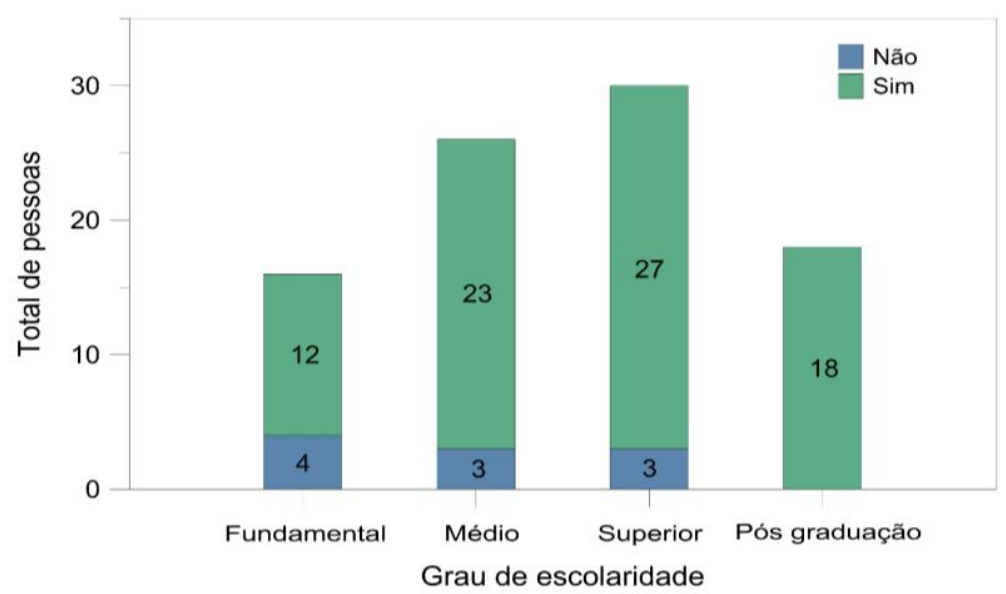

Figura 7: Tabulação cruzada sobre Impacto Ambiental e Grau de Instrução.

Muitos citaram o cenário atual da lagoa de Piratininga, como exemplo de impacto ambiental. Demonstrando, portanto, compreender o conceito apontado no primeiro artigo da Resolução n. 0001 do Conselho Nacional do Meio Ambiente (CONAMA, 1986), que apresenta o Impacto Ambiental como "qualquer alteração das propriedades físicas, químicas, biológicas do meio ambiente, causada por qualquer forma de matéria ou energia resultante das atividades humanas, que afetem diretamente ou indiretamente: a saúde, a segurança, e o bem estar da população; as atividades sociais e econômicas; a biota; as condições estéticas e sanitárias ambientais; a qualidade dos recursos ambientais".

No que se refere à percepção sobre quais são os principais problemas ambientais existentes na área em que residem (Tabela 2), enumerando-os em ordem de importância, verifica-se, que $48 \%$ consideram o lixo/resíduos expostos, seguido de poluição das águas com $46 \%$. 
Tabela 2: Principais problemas ambientais descritos.

Nível de importância

Problemas Ambientais

\begin{tabular}{|l|l}
+ & Lixo/Resíduos expostos \\
+ & Poluição das águas \\
Queimadas \\
Desmatamento \\
Erosão \\
Falta de saneamento \\
Construções em locais impróprios \\
Caça e pesca
\end{tabular}

Fonte: Autoria própria (2020).

Nota-se que apesar da poluição e descarte irregular de resíduos figurarem nas primeiras opções, suas causas locais, que estão principalmente associadas à falta de saneamento básico e construções em locais impróprios, aparecem entre as últimas opções. A área, que compreende o sistema lagunar e sua faixa costeira adjacente, sofreu diversas alterações antrópicas nas últimas décadas (PROJCONSULT, 2015), tais como: mudanças no sistema de urbanização, (alterações no plano diretor e gabarito de altura de edifícios na região oceânica, que permitiram a construção de edifícios residenciais em sua orla); ocupações irregulares, (comerciais e residenciais) nas margens das lagoas (que aumentaram o aporte de esgoto doméstico, lançado in natura nos corpos d'água) e; deficiência no serviço de coleta e transporte de resíduos sólidos (tendo em vista que esta área é um dos mais importantes polos de turismo e lazer de Niterói). Tais ações causam danos qualitativos e quantitativos, podendo levar desde a diminuição da qualidade da água quanto à extinção de espécies de sua biota (ANA, 2013).

Quando indagados sobre como os entrevistados contribuem para solução dos problemas ambientais locais (Figura 8), 56\% responderam, preservando o ambiente e $28 \%$ responderam, não acumulando lixo/resíduo. É perceptível que os moradores possuem a intenção de promover ações sustentáveis, já que, grande parte dos participantes disseram que não realizam descartes de lixo/resíduos indevidos. Assim, fica evidente a necessidade de informações mais direcionadas a esta população, que forneçam dados efetivos sobre os impactos negativos de ações não-sustentáveis, praticadas pelos moradores da região oceânica de Niterói. Estas informações podem produzir um efeito positivo e modificar a postura de vários moradores desta região. 


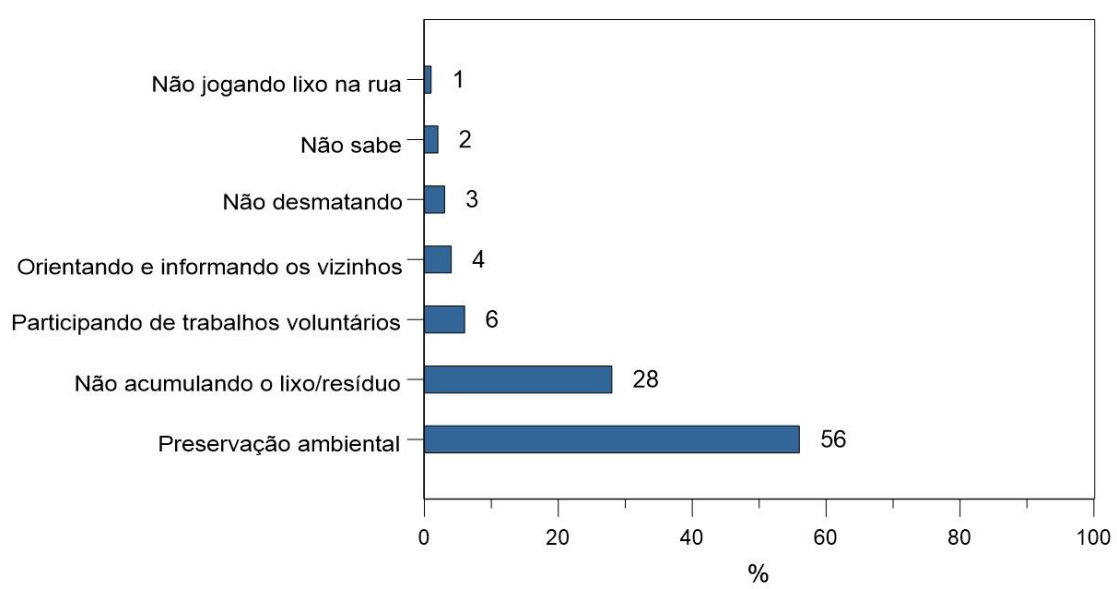

Figura 8: Atos de contribuição social citada pelos entrevistados.

Foi notória a preocupação dos moradores em relação ao lixo/resíduo sólido, principalmente, em evitar que estes cheguem até as lagoas. Houve comentários sobre a presença de pescadores externos a região e turistas, principalmente nos finais de semana e os lixos/resíduos abandonados durante as atividades de pesca e lazer.

Ao serem questionados sobre a responsabilidade por cuidar do meio ambiente, $98 \%$ das respostas atribuem a todos, envolvendo a população local, turistas, município, estado e governo. Tal percepção está alinhada ao ressaltado por Miranda (2011, p.19), onde o meio ambiente, como bem a ser juridicamente protegido, enquadra-se na categoria daqueles que ultrapassam a esfera puramente individual na medida em que os efeitos da degradação ambiental passam a ter reflexo coletivo. Esta é a mesma percepção da legislação ambiental brasileira (BRASIL, 1981).

A Política Nacional do Meio Ambiente, Lei Federal N 6.938 (BRASIL, 1981), demonstra obediência à Constituição Federal brasileira ao estabelecer instrumentos que visem alcançar seus objetivos de preservação, melhoria e recuperação da qualidade ambiental propícia à vida, tornando efetivo o direito de todos ao meio ambiente ecologicamente equilibrado, conforme consta na Constituição Federal. O caput do Art. 225 destaca que, "Todos têm o direito ao meio ambiente ecologicamente equilibrado, bem de uso comum do povo e essencial à sadia qualidade de vida, impondo-se ao Poder Público e à coletividade o dever de defendê-lo e preservá-lo, para as presentes e futuras gerações" (BRASIL, 1988). Demonstrando como a política é objetiva quanto a responsabilidade.

Nesse sentido, deve-se pontuar que a Educação Ambiental surge como ferramenta capaz de auxiliar as pessoas para que possam perceber o seu meio a partir de outros estímulos e visões. Conscientizando-se, da necessidade de preservação e da compatibilização entre a utilização dos recursos naturais e o desenvolvimento econômico (FRANCO, et al., 2012, p. 158). 
Em relação à infraestrutura local, $97 \%$ dos entrevistados têm sistema de coleta regular domiciliar de lixo e $3 \%$ não sabiam sobre a coleta, uma vez que apenas armazenam o lixo e o colocam nos coletores e caçambas. A responsabilidade pela coleta de lixo e destinação no município é da Companhia Municipal de Limpeza de Niterói (CLIN), que divide a cidade em 13 distritos, sendo Piratininga pertencente ao $9^{\circ}$ e Itaipu ao $11^{\circ}$ (CLIN, 2019). Deve-se ressaltar, entretanto, que apenas 3 a $5 \%$ das 565 toneladas de resíduos domiciliares e 200 toneladas de resíduos públicos são reciclados.

Quando abordados sobre a existência do serviço de coleta seletiva (Figura 9), 49\% dos entrevistados informaram que sim, indicaram que ela ocorre; $25 \%$ alegaram que não ocorre; enquanto $26 \%$ disseram que talvez. Isso demonstra a carência de informações sobre a coleta e destinação de resíduos sólidos em Niterói. Este resultado indica a necessidade de divulgação e oportunidade de alinhamento entre a gestão pública e a comunidade. Em 1991, a CLIN iniciou o projeto de coleta seletiva de lixo em Itaipu. Em 1997, o programa recebeu maior infraestrutura e foi ampliado e aprimorado ao sistema de recolhimento porta a porta. O programa consiste em coletar os resíduos sólidos recicláveis (papel, plástico, vidro e metal), após contato e cadastro do morador/gerador, dando uma destinação final adequada. A empresa informa que todo resíduo coletado seletivamente na cidade de Niterói é doado para duas cooperativas de catadores locais.

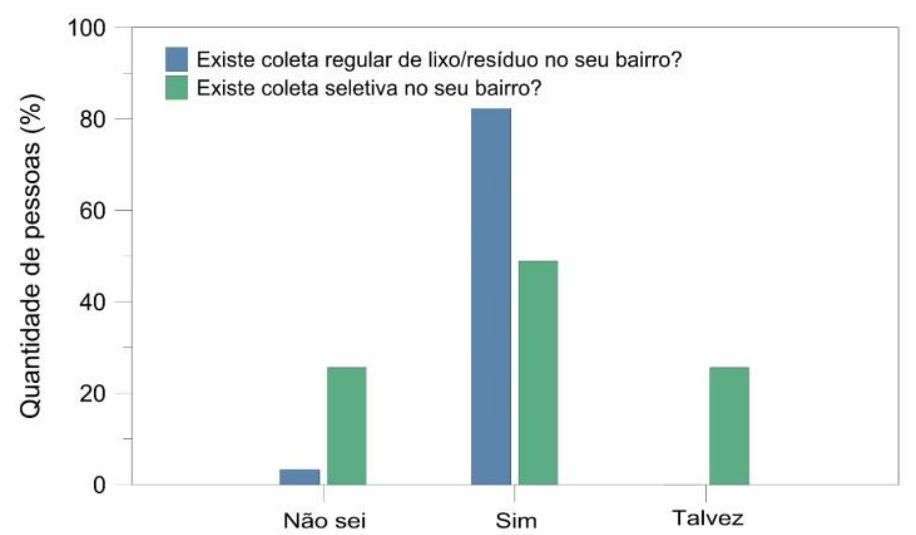

Figura 9: Questionamento sobre coleta regular x Coleta Seletiva.

Apesar da importância dada pelos moradores ao tema, resíduos, percebe-se, a falta de proatividade em buscar alternativas disponíveis na região. Ressalta-se, assim, a importância da adoção de programas de educação ambiental associados às atividades que ocorrem na região para que a população perceba que pode agir individualmente e coletivamente na busca de soluções, conforme conceito proposto por Reigada e Reis (2004). A Educação Ambiental é o primeiro passo para alcançar a sustentabilidade de forma integrada, contribuindo para a implementação e sucesso dos programas ambientais locais, permitindo que, todo participante auxilie na preservação ambiental e na inserção social. 
Quando questionados sobre a reflexão de reutilização antes de descartar algo no lixo (Figura 10), boa parte dos entrevistados indicou que havia essa preocupação (59\%). Quando questionados sobre que tipo de lixo/resíduo era gerado em sua residência em maior quantidade, $37 \%$ responderam que se tratava de restos de alimentos (orgânicos) e, na sequência os plásticos, com $33 \%$.

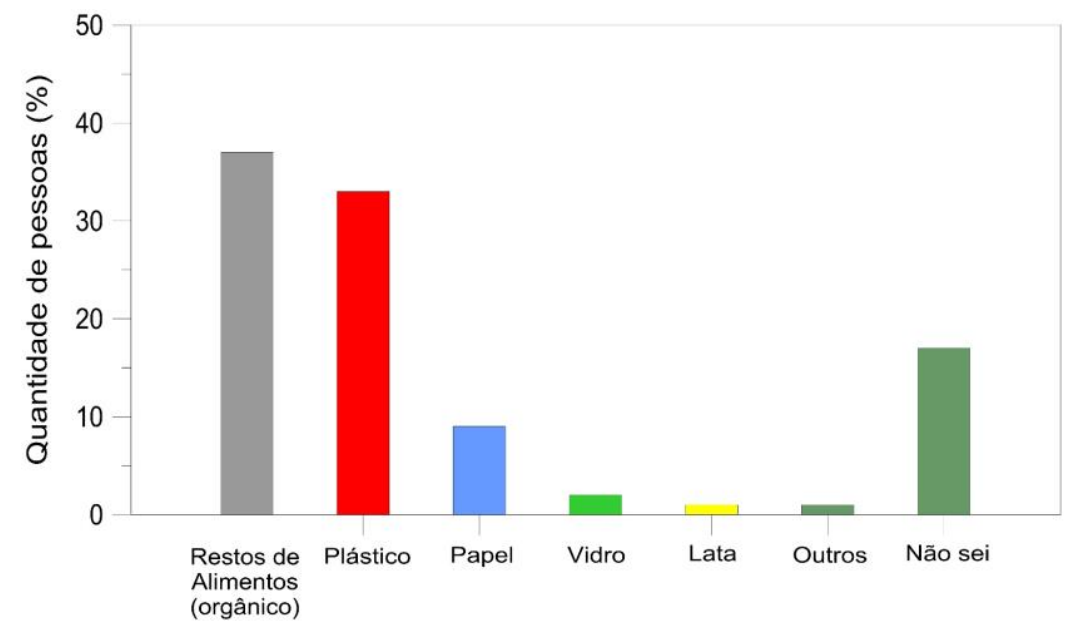

Figura 10: Percentuais de resíduos gerados em maior quantidade pela comunidade.

O maior percentual de resíduos orgânicos está em conformidade com os dados de caracterização nacional de resíduos sólidos publicada na versão preliminar do Plano Nacional de Resíduos Sólidos (MMA, 2020), que apontou que os resíduos orgânicos correspondem a mais de 50\% do total de resíduos sólidos urbanos gerados no Brasil. A legislação federal, por meio da Política Nacional de Resíduos Sólidos (Lei 12.305/2010), aponta em seu artigo 36, inciso $\mathrm{V}$, a compostagem como alternativa para o tratamento desse tipo de resíduo (BRASIL, 2010). Assim, entende-se que o estímulo da compostagem da fração orgânica dos resíduos, assim como a implantação da coleta seletiva e a disposição final ambientalmente adequada dos rejeitos, faz parte das obrigações dos municípios instituída pela Lei 12.305/2010. Para 98,9\% dos entrevistados, o lixo/resíduo descartado de forma inadequada pode causar problemas/impactos negativos às Lagoas.

Para o questionamento sobre separar e recolher seu lixo/resíduo quando está em atividade de lazer em local público (praias, parques, lagoas e praças), $93 \%$ citaram que sim, $4,4 \%$ as vezes e $2,2 \%$ afirmaram que não recolhiam seus lixos/resíduos. Na Figura 11 pode ser observada a representação dos percentuais por tabulação cruzada entre as respostas sobre o hábito de separar e recolher o lixo/resíduo e a possibilidade do material descartado de forma incorreta causar danos ao meio. 


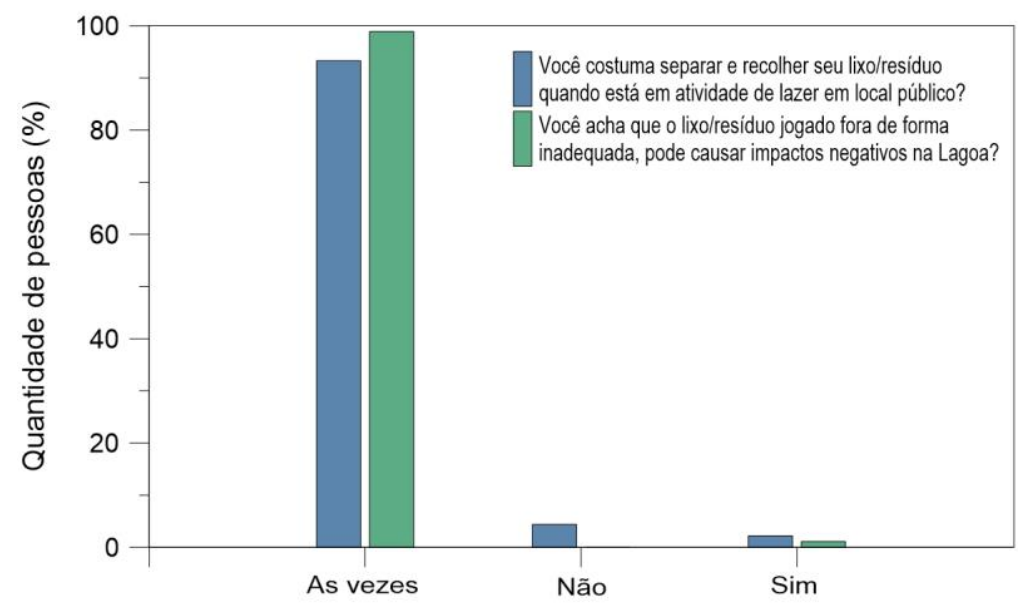

Figura 11: Questionamento sobre descarte de resíduos sólidos.

A presença de resíduos sólidos em áreas costeiras tem sido apontada em diversos trabalhos (ARAÚJO; COSTA, 2007; MOORE et al., 2011). Um em específico, realizado por Timbó (2019), descreve o diagnóstico da percepção ambiental dos usuários das praias de Itaipu, quanto à presença de resíduos sólidos. Timbó (2019) conclui que a praia de Itaipu foi considerada suja e frequentadores relataram que o plástico era o resíduo mais abundante. Os frequentadores também afirmaram que depositavam seus resíduos na lixeira, e atribuíram a presença destes na areia à falta de educação da população, citando que a responsabilidade de manter a praia limpa era de todos (poder público, comerciantes, banhistas, moradores e usuários). A presença dos resíduos nas praias, além de impactar visualmente o ambiente, traz consigo diversas consequências como a perda de potencial turístico, prejuízos para os pescadores, riscos à navegação, danos aos organismos marinhos e a saúde pública (OLIVEIRA, 2012).

Quando questionados sobre o conhecimento a respeito dos Microplásticos (Figura 12), 62\% dos entrevistados relatam ter noção do que se tratava, mas $38 \%$ não tinham nenhuma informação. Os microplásticos são definidos como detritos plásticos de tamanho inferior a $5 \mathrm{~mm}$, e são preocupantes em sistemas costeiros e marinhos. Podem ser classificados baseados em suas fontes como, primários e secundários. Os microplásticos possuem também, capacidade de absorver inúmeros contaminantes químicos, incluindo metais pesados e poluentes orgânicos persistentes (SAPEA, 2019). 


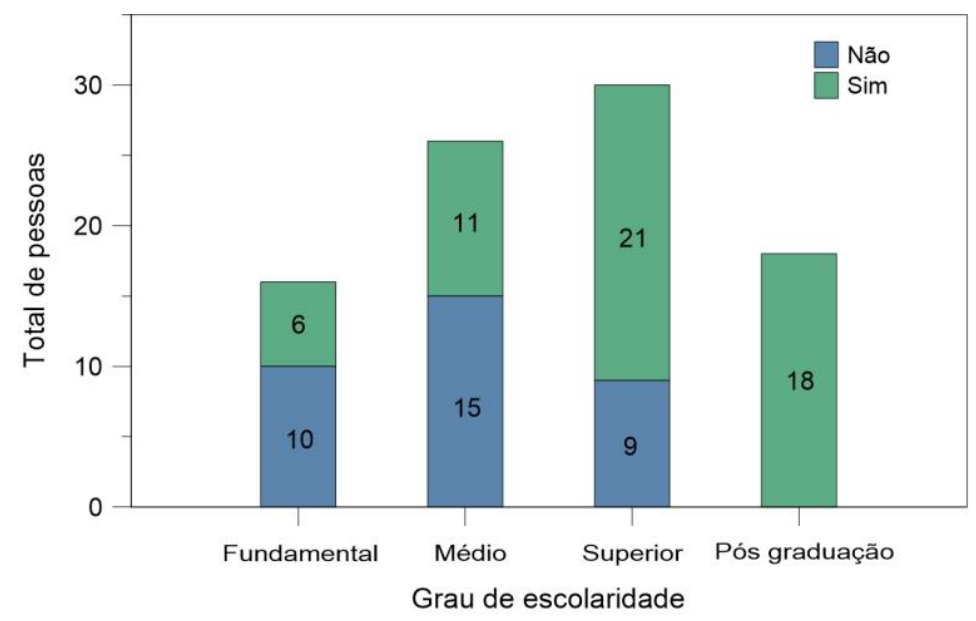

Figura 12: Percepção ambiental referente ao conceito de Microplásticos x Grau de Instrução.

A maioria dos entrevistados se mostrou favorável à proibição da distribuição de canudos e sacolas plásticas por parte dos estabelecimentos comerciais $(87 \%)$. Ocorreram observações por parte dos entrevistados quanto a este aspecto: "Sim, inclusive apoio a proibição também da comercialização"; "Proibir e substituir por papel ou não vender a sacola normal, plástica"; "Não adianta proibir alguns materiais e compensar em outros. O trabalho de reciclagem, a reutilização. Assim como desenvolvimento de materiais que degradam mais rápido no meio ambiente deveriam ser o foco"; "Canudos sim, porém, as sacolas representam mais uma maneira de ganhar dinheiro através do consumidor. Se realmente estivessem preocupados com o meio ambiente não haveria plástico algum nos estabelecimentos comerciais"; "Acho que deveria proibir plástico em geral, não só sacolas e canudos".

Nota-se, que apesar da aprovação, há o descontentamento com a legislação e forma de aplicação relacionada às sacolas plásticas. Os canudos plásticos são muito abundantes e se espalham facilmente, provocando dificuldade em seu recolhimento, e estão entre os materiais mais encontrados nas praias (FARIAS, 2014), o que a população demonstra perceber e concordar. Porém, em relação às sacolas, a população vê como assertiva a decisão, mas espera o retorno também dos fabricantes no oferecimento de material biodegradável, uma vez que pelas leis estaduais há o encargo apenas para os consumidores e de certa forma para os comerciantes.

Quando questionados se esta ação contribui para reduzir drasticamente a quantidade de material depositado nos lixões, rios, lagoas, praias e oceano, $74 \%$ responderam que sim, $20 \%$ talvez, e $5,6 \%$ responderam que não.

O Rio de Janeiro foi a primeira cidade brasileira a banir canudos plásticos, com a implementação da Lei Estadual oㅜ 6.384 de 04 de julho de 2018, que posteriormente, foi revogada por não ter previsto prazo para à 
adequação dos estabelecimentos. Esta adequação foi inclusa na Lei Estadual no 6.458/2019 (RIO DE JANEIRO, 2019). Em Niterói existe um projeto de lei elaborado nos mesmos moldes do projeto de lei realizado no Rio de Janeiro, que impede a utilização desse material tão impactante ao meio ambiente em estabelecimentos comerciais. De acordo com a matéria publicada, a motivação deste documento foi um pedido de entidades que promovem ações de educação ambiental, alinhados ao Instituto Estadual do Ambiente - INEA (LITWAK, 2018).

A Lei Estadual no 8.473 de 15 de julho de 2019, tem como principal objetivo reduzir o excesso de sacolas plásticas descartadas no meio ambiente. Segundo a Associação de Supermercados do Estado do Rio de Janeiro (ASSERJ, 2019), houve uma redução de cerca de 50\% na entrega das sacolas, desde que a lei que restringe a distribuição do produto passou a vigorar em 2019. Segundo matéria publicada na Agência Brasil (GANDRA, 2020), antes da criação da lei, cerca de 4 bilhões de sacolas plásticas eram distribuídas no Rio de Janeiro a cada ano, o que significa que mais de 300 milhões de sacolas plásticas eram entregues mensalmente no estado do Rio de Janeiro. Com a aplicação da lei, esse número caiu para menos de 200 milhões de sacolas por mês.

Com a finalidade de identificar a conjuntura local, acerca do alinhamento promovido através da gestão pública sobre temas ambientais, os entrevistados foram questionados sobre sua participação em pesquisas realizadas pela prefeitura ou pelo governo. Do total dos entrevistados, $81,1 \%$ disseram que não participaram de pesquisas desenvolvidas em âmbito local. A justificativa foi que, não percebiam interesse do poder público em uma aproximação para um alinhamento com os problemas locais.

E por fim, ao perguntar sobre participar de uma atividade ambiental promovida nas lagoas (Figura 13), 44\% foram positivos, muitos justificaram não ter tempo disponível para participar de ações. Percebe-se, portanto, que a população se indigna com o estado de conservação local, mas se omite da participação para contribuir com a solução. Esses dados apontam para a necessidade de aproximação do poder público para a gestão ambiental, como destacado por Quintas (2004), para retirar da população o sentimento de impotência frente às questões ambientais e reacender a crença na prática do Poder público visando impedir a degradação e promover a recuperação. 


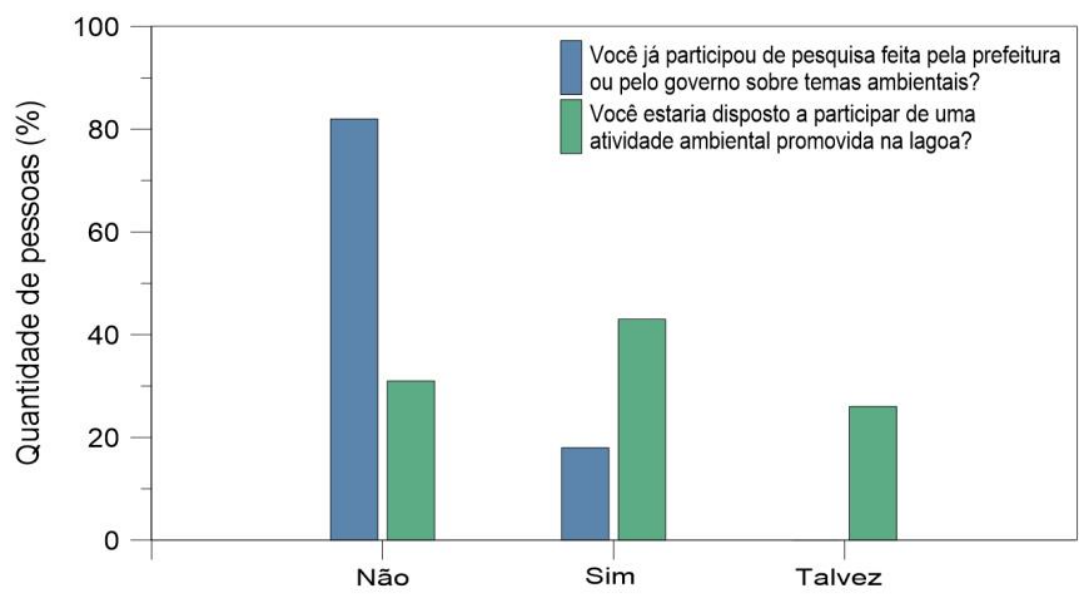

Figura 13: Disponibilidade de participar de atividades ambientais promovida nas lagoas.

\section{Considerações Finais}

O desenvolvimento deste estudo permitiu analisar a percepção ambiental dos moradores da região das praias oceânicas de Niterói, especificamente situadas no entorno das lagoas de Piratininga e Itaipu. Constatou-se, que grande parte dos entrevistados demonstrou uma visão plausível referente ao meio ambiente. Mesmo sendo uma entrevista pautada em um questionário, considerada uma técnica que possibilita obter informações de muitas pessoas de maneira rápida, ordenada e mensurável, foi possível estimular o entrevistado a falar, sem intervir em suas respostas.

Neste sentido, a visão predominante é que existe a necessidade de ações por parte do poder público, principalmente pelo cenário atual da área de estudo, uma vez que se constatou a existência de uma gestão conflitante entre Estado, Município e população local. Embora ações remediadoras tenham sido executadas, visando a recuperação ambiental da área de estudo, verificaramse, algumas tentativas baseadas principalmente em ações paliativas que tiveram resultados comprometidos, evidenciando uma ausência de gestão presencial e contínua no tocante às questões ambientais. Um exemplo, que reforça este sentimento, é a ausência de estudos promovidos pelo município, que contemplem o envolvimento direto da comunidade local. Possivelmente, esta ausência provocou uma desmotivação no envolvimento da comunidade e, atualmente, a maioria não apresenta interesse em participar de atividades promovidas na lagoa, como sugeridas por este trabalho.

Por fim, vale ressaltar que a participação popular deve ser estimulada para a construção da preservação do meio ambiente, sendo escutada de forma clara e ampla. Este envolvimento permite construir na comunidade um reconhecimento do seu papel como integrante e multiplicador de ações de sustentabilidade para fortalecer a gestão ambiental local. Assim, conclui-se que ações de Educação Ambiental são necessárias como um instrumento da política pública ambiental, pois auxiliarão na compreensão de que todos os 
atores sociais têm sua parcela de responsabilidade e comprometimento com a realidade local e global.

\section{Agradecimentos}

Ao Programa de Pós-Graduação em Engenharia de Biossistemas PGEB, ao Instituto de Física - IF (Laboratório de Radioecologia e Alterações Ambientais - LARA) e à Universidade Federal Fluminense pela oportunidade de desenvolvimento da pesquisa.

\section{Referências}

ADDISON, E. E. A percepção ambiental da população do município de Florianópolis em relação à cidade. 152 folhas. Dissertação (Mestrado em Engenharia de Produção) - Universidade Federal de Santa Catarina, Florianópolis, 2003.

ANA. Agência Nacional de Águas. Monitoramento da Qualidade da Água em Rios em Reservatórios: Variáveis e parâmetros de Qualidade de água em Rios e reservatórios. 2013. Disponível em: <https://www.ana.gov.br/panoramadas-aguas>. Acesso em: 15 fevereiro de 2020.

ARAÚJO, M.C.B.; COSTA, M. Análise da contribuição ribeirinha para a contaminação de resíduos em uma praia isolada no nordeste brasileiro. Management of Environmental Quality, 18 (1): 6-12. 2007.

ASSERJ. Associação de Supermercados do Estado do Rio de Janeiro. Em seis meses, cerca de um bilhão de sacolas plásticas deixam de ser distribuídas por supermercados no Estado do Rio de Janeiro. Dez. 2019. Disponível em: <https://asserj.com.br/supermercados/2019/12/em-seis-mesescerca-de-um-bilhao-de-sacolas-plasticas-deixam-de-ser-distribuidas-porsupermercados-no-estado-do-rio-de-janeiro/>. Acesso em: 20 agosto de 2020.

BRANDON K.; FONSECA G.A.B; RYLANDS A.B.; SILVA J.M.C. Conservação brasileira: Desafios e oportunidades. Megadiversidade, Vol.1, nำ1. 2005.

BRASIL. Conselho Nacional do Meio Ambiente - CONAMA. Resolução no 001/1986, de 23 de janeiro de 1986. Dispõe sobre critérios básicos e diretrizes gerais para a avaliação de impacto ambiental. Diário Oficial da União, Brasília, DF, 17 jan. 1986.

BRASIL. Constituição Federal de 1988. Disponível em: $<$ https://www.planalto.gov.br/ccivil 03/Constituicao/Constituicao.htm>. Acesso em 16 agosto de 2020.

BRASIL. Lei 6.938, de 31 de agosto de 1981. Dispõe sobre a Política Nacional do Meio Ambiente, seus fins e mecanismos de formulação e aplicação, e dá outras providências. Diário Oficial da República Federativa do Brasil. Brasília, 02 set. $1981 . \quad$ Disponível em: <http://www.planalto.gov.br/ccivil 03/leis/l6938.htm>. Acesso em: 15 fevereiro de 2020. 
BRASIL. Lei Federal $n^{\circ}$ 12.305, de 02 de agosto de 2010. Institui a Política Nacional dos Resíduos Sólidos. 2ª Edição - Brasília: Câmara dos Deputados, Edições Câmara, 2012.73 p. - (Série legislação; n. 81). 2012. ISBN 978-85736-5972-6.

CARVALHIDO, V. V. R. Do "direito à vez" à vez aos direitos: Conflitos e representações acerca do espaço e do trabalho no Canto de Itaipu. 97 Folhas. Dissertação. (Mestrado em Antropologia). Universidade Federal Fluminense, Niterói. 2012.

CLIN - Companhia de Limpeza de Niterói. Projeto de Coleta Seletiva. Local de publicação. 2020.2 Disponível em: <http://www.clin.rj.gov.br/?a=coletaseletiva $>$, Acesso em: 01 setembro de 2020.

COIMBRA, J. A. A. O outro lado do meio ambiente. São Paulo: CETESB, 1985.

DOMENES, A. C.; PAULINO, F. B.; COSTA, T. H.; JUNQUEIRA, T. H. B. Redes sociais e o meio ambiente: novo conceito de comunicação para preservação do planeta através de redes sociais. Fórum de Administração, v. 2, n. 4, p. 111-124, 2012.

FAGGIONATO, S. Percepção Ambiental. Material de Apoio - Textos, 2002. Disponível em: http://educar.sc.usp.br/Ciências Biológicas/textos/m a txt4.html. Acesso em: 20 fevereiro de 2020.

FARIAS, S.C.G., Accumulation of waste disposal in coastal environments: the ocean beach Piratininga - Niterói - Rio de Janeiro - Geo. UERJ 25. Ano 16, no. 25, v.2. pp.276-296, 2014.

FERREIRA, M. C. Associativismo e contato político nas regiões metropolitanas do Brasil: 1988-1996. Revista Brasileira de Ciências Sociais, v. 14, n. 41, 1999.

FONSECA, J. S.; MARTINS, G. A. Um curso de estatística. São Paulo: Atlas; 1996.

FRANCO, A. R.; MORAIS, G. A. C. de; NETO, J.D.; LOPES, J.C.C.; LEUCAS, H. L. B. de; GUADALUPE, D. C.; BARROS, M. D.M de. Estudo de percepção ambiental com alunos de Escola Municipal localizada no entorno do Parque Estadual da Serra do Rola-Moça. Ambiente \& Educação. v.17 (1), p. 155175, 2012.

GANDRA, Alana. AGÊNCIA BRASIL. Supermercados RJ tiram de circulação 2 bilhões de sacolas plásticas. 26 jun. 2020.

GUIMARÃES, M. Sustentabilidade e Educação Ambiental. In: CUNHA, S.B. \& GUERRA, A.J.T. (orgs.). A Questão Ambiental: Diferentes Abordagens. Rio de Janeiro, RJ: Bertrand Brasil, p. 81-105. 2003. 
HYDROSCIENCE, Consultoria e Restauração Ambiental Eirelie. Evolução Histórica dos Usos do sistema Lagunar e seu entorno. Elaboração de estudos para Análise da condição ambiental do Sistema lagunar Piratininga-Itaipu. Município de Niterói, 2018.

HUTTNER, L. R. G. É fake news?: como elementos do jornalismo são utilizados para elaboração de "notícias falsas". Dissertação (Mestrado em Comunicação) - Universidade Federal do Rio Grande do Sul, Porto Alegre, 2020. Disponível em: <http://hdl.handle.net/10183/206028>. Acesso em: 20 agosto de 2020.

IBGE - Instituto Brasileiro de Geografia e Estatística. Censo Demográfico 2010. Rio de Janeiro: IBGE, 2010. Disponível em: $<$ http://censo2010.ibge.gov.br>. Acesso em: 10 fevereiro de 2020.

IBGE - Instituto Brasileiro de Geografia e estatística. Pesquisa Nacional de Amostra por Domicílio, 2015. Disponível em: $<$ https://www.ibge.gov.br/estatisticas/sociais/populacao.html>. Acesso em 20 de agosto de 2020.

INEA. Instituto Estadual do Ambiente. Entrega autorização ambiental à Prefeitura de Niterói para a revitalização da Lagoa de Piratininga. Disponível em: <http://www.inea.ri.gov.br/inea-entrega-autorizacao-ambientala-prefeitura-de-niteroi-para-a-revitalizacao-da-lagoa-de-piratininga/>. Acesso em 20 de agosto de 2020.

INEA. Instituto Estadual do Ambiente. Reserva Extrativista Marinha de Itaipu. Disponível

em:<http://www.inea.ri.gov.br/Portal/Agendas/biodiversidadeeareasprotegidas/ UnidadesdeConservacao/INEA0047363\#/Informacoesuteis $>$. Acesso em: 14 de setembro de 2020.

KRZYSCZAK, F. R. As diferentes concepções de meio ambiente e suas visões. Revista de educação do IDEAU, v. 13, n. 23, Jan- Jun, p. 1 -18, 2016.

LIMA, G.P. Educação ambiental crítica: da concepção à prática. Revista Sergipana de Educação Ambiental.v.1, n.2, p.33-54. 2015.

LITWAK, P. A. Canudo de plástico pode ser banido de Niterói. O GLOBO. 9 dez. 2018. Disponível em: https://oglobo.globo.com/rio/bairros/canudo-deplastico-pode-ser-banido-em-niteroi-23289849. Acesso em: 7 setembro de 2020.

MIRANDA, R. N. Direito Ambiental. São Paulo: Rideel, - Coleção de direito Rideel. p.19. 2011.

MMA. Mistério do Meio Ambiente. Responsabilidade Socioambiental. Disponível em: < https://www.mma.gov.br/cidades-sustentaveis/residuossolidos/gest\%C3\%A3o-de-res\%C3\%ADduos-org\%C3\%A2nicos.html> Acesso em: 05 setembro de 2020. 
MOORE, C.J.; LATTIN, G.L.; ZELLERS, A.F. Quantidades e tipos de plásticos provenientes de dois rios urbanos que escoam para águas costeiras e praias do Sul da Califórnia (Estados Unidos). Revista da Gestão Costeira Integrada, v.11, n.1, p.65-73. 2011.

NITERÓI. Decreto no 2.874, de 13 de dezembro de 2011. Considera Patrimônio Cultural de Natureza Imaterial a pesca artesanal de Itaipu. Niterói: Câmara Municipal, 2011.

NITERÓl. Obra de desobstrução do Túnel do Tibau, na Lagoa de Piratininga, começa este mês. In: Prefeitura de Niterói. RJ, 7 ago. 2020. Disponível em: <http://niteroi.rj.gov.br/index.php?option=com content\&view=article\&id=6794:2 020-08-07-20-08-23>. Acesso em: 5 setembro de 2020.

OLIVEIRA, M.C.B.R. Gestão de resíduos plásticos pós-consumo: perspectivas para a reciclagem no Brasil. 91 Folhas. Dissertação (Mestrado em Planejamento Energético), COPPE - Universidade Federal do Rio de Janeiro. 2012.

PRATTES, C. M. Associativismo: o princípio do fortalecimento das profissões. $2013 . \quad$ Disponível em:< http://www.fiepr.org.br/sindicatos/sindirepapg/News3263content205461.shtml > Acesso em: 5 setembro de 2020.

PROJCONSULT, Engenharia de projetos LTDA. Projeto Básico de Revitalização, Recuperação Ambiental do Complexo Lagunar Piratininga / Itaipu, Município de Niterói - RJ. Produto 15: Relatório final do projeto. 37p. 2015.

PROSUSTENTÁVEL. In: Prefeitura de Niterói. Niterói. RJ, 7 ago. 2020. Disponível em: <http://www.prosustentavel.niteroi.ri.gov.br/>. Acesso em: 5 setembro 2020.

QUINTAS, J. S. Educação no processo de gestão ambiental: uma proposta de educação ambiental transformadora e emancipatória. P. 113-140. In: Identidade da educação ambiental brasileira. Ministério do Meio Ambiente, 156 p. Brasília, 2004.

RAUPP, F. M.; BEUREN, I. M. Metodologia da pesquisa aplicável às ciências sociais. In. BEUREN, I.M. (Org.). Como elaborar trabalhos monográficos em contabilidade: teoria e prática. 3 ed. São Paulo: Atlas, Cap.3, p.76-97. 2006.

REIGADA, C.; REIS, M. F. C. T. Educação Ambiental para crianças no ambiente urbano: Uma proposta de pesquisa-ação. Ciência e Educação, v.10, n.2, p.149-59, 2004.

REIGOTA, M. O estado da arte da pesquisa em Educação Ambiental no Brasil. Pesquisa em Educação Ambiental. vol.2, №1, p. 33-66. 2007. 
RIO DE JANEIRO. Decreto no $\mathbf{4 1 . 2 6 6}$ de 16 de abril de 2008. Dispõe sobre a ampliação do perímetro definitivo do Parque Estadual da Serra da Tiririca, localizado nos municípios de Niterói e Maricá. Rio de Janeiro, 2008.

RIO DE JANEIRO. Lei no 6.384, de 04 de julho de 2018. Rio de Janeiro , 18 jul. 2018. p. 3-4.

RIO DE JANEIRO. Lei $\mathbf{n}^{\circ}$ 6.458, de 08 de janeiro de 2019. Disponível em: $<$ http://leismunicipa.is/xeokc>. Acesso em: 15 fevereiro de 2020.

RODRIGUES, M.S.; GOUVEIA, R.L. Percepção dos usuários acerca da problemática dos resíduos sólidos na praia de Boa Viagem, Recife-PE. In: ELDEIR, S.G. Resíduos sólidos [livro eletrônico]: perspectivas e desafios para a gestão integrada, 1. ed. - Recife: Edufrpe, v.2, p.75-81, 2014.

SAPEA - Science Advice for Policy by European Academies. A Scientific Perspective on Microplastics in Nature and Society. Berlin: SAPEA. 2019.

SEA (Secretaria do Ambiente) \& INEA. Estudo técnico para criação da Reserva Extrativista Marinha de Itaipu - RESEX ITAIPU. Niterói, RJ. 54p. 2013.

SEA, Secretaria de Estado do Ambiente. Plano de Manejo. Parque Estadual da Serra da Tiririca. 2015.

SILVA, A.C.M.; ARAÚJO, M.C.B.; SILVA-CAVALCANTI, J.S.; DIAS FILHO, M. Avaliação da Percepção Pública na Contaminação por Lixo Marinho de acordo com o Perfil do Usuário: Estudo de Caso em uma Praia Urbana no Nordeste do Brasil. Revista da Gestão Costeira Integrada, v.11, n.1, p.49- 55. 2011.

SILVA, E. L.; MENEZES, E. M. Metodologia da pesquisa e elaboração de dissertação. 4. ed. Florianópolis: UFSC, 2005.

TERAMUSSI, T.M. Percepção Ambiental de estudantes sobre o Parque Ecológico do Tietê, São Paulo-SP. 105 Folhas. Dissertação. (Mestrado em Ciência Ambiental). Universidade de São Paulo, São Paulo. 2008.

TIMBÓ, M.; SILVA, M. L.; CASTRO, R. O.; ARAÚJO, F.V. Diagnóstico da percepção ambiental dos usuários das praias de Itaipu e Itacoatiara quanto à presença de resíduos sólidos. Journal of Integrated Coastal Zone Management. Revista de Gestão Costeira Integrada, v.19, n.3, p.157-166, 2019.

VICENTE, A.R.P.; BERTOLINI. G.R.F.; RIBEIRO, I. Percepção da população quanto aos indicadores de sustentabilidade de Curitiba: A cidade sustentável do planeta. Revista Gestão \& Sustentabilidade Ambiental, v.4, n.2, p.268272, 2015. 